\title{
Proceeding
}

Supplementary Issue: Spring Conferences of Sports Science. Costa Blanca Sports Science Events, 14-15 June 2019. Alicante, Spain.

\section{Digital and non-verbal communication in preschool: A systematic review}

\author{
MANUELA VALENTINI ${ }^{1}$, MARIACHIARA MANCINI ${ }^{1}$, GAETANO RAIOLA ${ }^{2}$, ARIO FEDERICI $^{1}$ \\ 1 University Carlo Bo of Urbino, Italy \\ 2University of Salerno, Italy
}

\begin{abstract}
The aim of this research is to reflect on the importance, since preschool, of both verbal and non-verbal language, which is the unintentional communication or body language. This is done to assure a better selfawareness, to establish positive and effective relationships, to prevent conflicts and to empathically understand oneself and other people's feelings. Furthermore, students are digital natives, so they require digitally equipped environments, with which they are familiar from an early age. On the other hand, teachers are digital immigrants, because they have only come in contact with digital devices as adults; as a consequence, they pay the price for the generation gap which distinguishes them from digital natives, whose mindset is more involved in the dynamics of change and whose lives are symbiotically connected to technology. Therefore, teachers need an adequate training for media management in classrooms. The review process focused on 36 international articles (20 articles and 16 investigations) and 4811participants; the inclusion. Keywords: Non-verbal communication; Digital communication; Preschool; Children; Teachers.
\end{abstract}

\section{Cite this article as:}

Valentini, M., Mancini, M., Raiola, G., \& Federici, A. (2019). Digital and non-verbal communication in preschool: A systematic review. Journal of Human Sport and Exercise, 14(4proc), S997-S1016. doi:https://doi.org/10.14198/ihse.2019.14.Proc4.62

Corresponding author. University Carlo Bo of Urbino, Italy.

E-mail: manuela.valentini@uniurb.it

Supplementary Issue: Spring Conferences of Sports Science. Costa Blanca Sports Science Events, 14-15 June 2019. Alicante, Spain.

JOURNAL OF HUMAN SPORT \& EXERCISE ISSN 1988-5202

(c) Faculty of Education. University of Alicante

doi:10.14198/jhse.2019.14.Proc4.62 


\section{INTRODUCTION}

Communication is a powerful force capable of anything.

Communication (from the Latin "communico" = make common, share) is the exchanging of information from an individual or a place, to another. The body is a fundamental component of communication: in cooperation with a clear and efficient verbal channel, it makes the message effective. The body is actually always speaking and it allows the individual to connect with the environment. Non-verbal communication is formed by the body as a whole and by what it expresses and communicates. (Del Nista P.L., Parker J., Tasselli A., 2014, p. 78). This type of communication is commonly considered to be universally intelligible and able to transcend the linguistic barriers. Nonetheless, finding the right words for any communicative situation isn't enough, we also need to pay attention to how they're expressed, considering the interlocutor and the context; the same situation could be perfectly appropriate in a culture but inappropriate in another, and vice versa. As a matter of fact, the mechanisms which generate communication are almost the same in every culture, but every culture tends to elaborate non-verbal messages in its own way. (Patterson M. \& Quadflieg S., 2016, p. 189).

For a right interpretation of a message, we need to understand the non-verbal channel in a given context and compare it to the verbal one. We talk about adequate or coherent communication when there's a correspondence between the two channels; we talk about inadequate or incoherent communication when there's a lack of correspondence and the verbal language is in opposition to the non-verbal language. (Valentini M. \& Castriconi S., 2007, p. 68).

The main components of non-verbal communication are 4: paralanguage, kinesics, proxemics and haptics, to which we can add chronemics and vestemics. The paralinguistic components of the message, called prosodic units, differ in duration (full or empty breaks and speed of execution),intensity (volume and accent),tone (as expression of emotions),intonation, phonatory vocal quality expressed through the voice. (Ferranti C., 2014, p. 3; Matsumoto D. \& Hwang H., 2016, p. 92); kinesics studies posture, gestures and expressions, including facial mimicry and the looks which accompany speaking (Ferranti C., 2014, p. 1); proxemics studies the space within communication: E. T. Hall has observed that the relational distance between people is related to physical distance (Hall E. T., 1966); he has then distinguished four interpersonal zones: (intimate, personal, social, public); haptics is the interaction involving touch and has a pivotal role in relational management (Matsumoto D., Hwang H. \& Frank M., 2016, p. 393): it consists in the actions of touch between the interlocutors during the conversation. The language of children in preschool isn't fully developed yet, therefore, in order for their communication to be effective, they need to use their body or some parts of it to engage with their peers and with adults. For a child, communicating means being heard and, therefore. understood. To do so, they use their own language, not always made up of words, but of expressions and behaviours which are equally expressive.

The capability to express and understand emotions non-verbally is among the most important acquisitions in childhood. (Boyatzis C. \& Satyaprasad C., 1994, p. 37). Children's faces could be considered their most powerful and truthful means of communication, particularly at this age: through a smile, a gaze, a tear or simply by pulling a face they communicate their deepest ideas and inform us on their inner state. (Mui P., Goudbeek M., Swerts M., Hovasapian A., 2016, p. 78). The ability to interpret non-verbal expressions already emerges in childhood; during this period, the subjects also show the acquisition of linguistic skills needed to comprehend verbally expressed emotions and the ability to notice the discrepancy between verbal and nonverbal displays, reaching an adequate level of sophistication (Josephs I., 1994, p. 302): the ability to read 
into non-verbal behaviours seems to develop faster than the ability to create these messages; so both in nonverbal and verbal behaviour, comprehension precedes production (Boyatzis C. \& Satyaprasad C., 1994, p. 48).

Children star to use gestures before being able to speak, and during the first years of language development, gestures provide a way to integrate and adjust their spoken language (Boyatzis C. \& Satyaprasad C., 1994, p. 48).

In preschool age, gesticulating is an already consolidated skill in a child's repertoire; in fact, it has a fundamental role in preschool: pupils' gestures often show information on their way of thinking which they don't express through language; gestures can therefore help teachers to know their students. The teacher's gestures makes the didactic material more interesting and makes the learning process more involving (Sanseviero et al., 2019); on the contrary, the lack of gestures makes the teacher strict and boring for the students. Thus, the teacher's gestures help students to understand complex instructions and significantly facilitate the learning process, as shown by McNeil et al. (2000) e Valenzeno et al. (2003) (Cameron H. \& Xu X., 2011, p. 166). In addition, accompanying children's outputs with the right pace spreads a caring listening environment which enables communication. Non-verbal elements are fundamental for the teachers, who can reach a global and accurate comprehension if they take into consideration the child's expressions and behaviours but also what they non-verbally communicates while speaking or moving. (D'Angiò G., 2009, p. 2).

Today, humanity is undergoing a new revolution, which has entailed significant changes in the approach to culture, work and free time. Differently from the previous revolutions, this one is guiding the transformation of society in all its forms: it affects relationships and has to do with everyday life. (Scialò L., 2016).

The digital revolution, which started in the industrialized countries at the end of the 1950s, consists in the transition from mechanical and electronic analogue technology, to the electronic digital one. The introduction of digitalization and the multiplication of the channels to obtain information have radically transformed the ways of communication. (Grushka K., Donnelly D., Clement N., 2014, p. 358). Digital technologies actually allow a personalised and multidirectional communication, which takes advantage of the bidirectional channel of the web to address targeted and diverse messages based on the user's expectations and preferences. The new or digital media make this type of communication possible; compared to the previous ones, they're characterized by multimedia, interactivity and hyper textuality. (Grushka K., Donnelly D., Clement N., 2014, p. 359). Digital media have made communication easier, faster and more immediate, but this computer mediated communication lacks the paralinguistic elements of face-to-face conversation. It also lacks the feedback which allows the interlocutors to precisely identify the relational and social aspects. (Sproull \& Kiesler, 1986) (Radice G., 2017, p. 4). The dynamic of digital communication is relentless: in history, we have rarely witnessed such a fast and global development, capable of penetrating the habits of people belonging to such different cultures. This sudden development is also confirmed by the research of Zimic S. (2008) and Cinque T. and Brown A. (2014); as can be seen from Chart 1, said investigation demonstrates the increase in the Internet use within 6 years. In 2008, for example, $40 \%$ of the subjects used Internet 1 hour or less a day, while, in 2014, the percentage was cut down to 1\%. On the opposite, in 2008 only the $10 \%$ used Internet more than 5 hours a day; this data tripled in 2014, when the 35\% declared using Internet more than 5 hours a day. 
Table 1. Zimic S. (2008) e Cinque T. e Brown A. (2014) research comparison

\begin{tabular}{lcc}
\hline \multirow{2}{*}{ REFERENCE YEAR } & I USE THE INTERNET & I USE THE INTERNET \\
& 1 HOUR OR LESS A DAY & MORE THAN 5 HOURS A DAY \\
& (percentage data) & (percentage data) \\
\hline 2008 & $40 \%$ & $1 \%$ \\
2014 & $10 \%$ & $35 \%$ \\
\hline
\end{tabular}

With respect to the daily use time, the digital media, such as the computer and the smartphone, are most commonly used for communicative, informative and recreational purposes. (Mantovani S. \& Ferri P., 2008, p. 14). The fact that the recreational use is so well-established can prove their futility, but also, demonstrate their adaptive power; playing and learning by doing is, among all human activities, the most important to learn how to adapt to the world, through an incessant interchange between inventing and exploring. (Blabi B. \& Magaudda P., 2014, p. 15).

The spread of digital instruments has created a new generation: the "digital natives"; according to P. Ferri, within Italian territory we have been talking about "digital natives" from the beginning of 1996, linking the emerging of said generation with the launch of the first Internet browsers (December 1995 Netscape Navigator, January 1996 Microsoft's Internet Explorer) and, therefore, with the spread of the web (Mantovani S. \& Ferri P., 2008, p. 17). Children born from those years on have therefore lived in symbiosis with new technologies, which, starting from the computer, have multiplied. (I-pods, smartphones, tablets...). The subjects' familiarity with such a wide variety of "interactive displays" has shaped their way of learning, experiencing, communicating and, simultaneously, their approach to reality: for the natives, virtual reality is as real as the reality experienced through the senses (Ferri P., 2012, p. 1). The digital native's approach to knowledge is therefore founded on an investigation and discovery process which is evidence-based, collaborative, active, auto-organized and also centred on problem solving and knowledge sharing. Being or becoming digital means undergoing and yet performing a peculiar gestalt rearrangement of the traditional conceptual framework (Mantovani S. \& Ferri P., 2008, p. 28); it means living and experiencing time beyond the "time of the clock" modern paradigm and setting sights on a new dimension of cyberception of the time (Derrick de Kerckhove, 1991). This new approach has made children become used to receiving information very quickly (Prensky M., 2001, p. 2). Therefore, the expression "digital natives" currently pinpoints the generation born and raised with the Internet; this generation is always connected through smartphones or tablets and presents digital alphabetization and abilities. Marc Prensky (2001) coined the phrase "digital natives" in order to highlight the extent of this revolution, contrasting them with the "digital immigrants", to indicate the people born and raised in the United States after 1985. These people were born in a "multidisplay" society and consider technologies to be natural, without any discomfort in interacting or operating with them. Internet is the main communicative tool among natives, through which they can create an ongoing connection and exchange information with their peers. The success of social networks totally confirms the predominant use of the new technologies as an "extension of the social sphere" (Ferri P., 2012, p. 1).

The digital immigrants, also called "Gutenberg natives", are therefore all the subjects born before 1985, raised and educated in the social and economic universe of the Gutenberg galaxy (Mantovani S. \& Ferri P., 2008, p. 15); they haven't lived in digitally-offered ways, so, they have to manage the movement, translation and change trauma (Brabazon T., 2014, p. 89), adjusting to the new socio-technological environment. There are two types of subject in the technological immigrants category: teachers and parents (Mantovani S. \& Ferri P., 2008, p. 104). The representations that parents have towards technology and their ways of taking possession of the computer and telematic tools are fundamental to understand children's procedures in 
taking possession of the digital; the digital native's first contact with computers, phones, videogames consoles and other digital media takes place within the family, the place where they acquire their digital abilities. Finally, parents seem to be less "technophobic" and more confident than teachers about the children's abilities of using technology, both at home and in a school context. In a world in which children are "growing digitally", parents play an important role in teaching them how to use technology safely; sharing this with the caregiver promotes learning and interactions. (Bozzola E. et al., 2018, p. 5) The digital immigrants parents' positive emphasis on technology can play a significant part in the introduction of technologies in school, so that children acquire an effective education relationship and an adequate digital competence (Mantovani S. \& Ferri P., 2008, p. 130).

In an omnipresent computer age, the way in which school runs the use of technology is essential for successful teaching and learning. (McRae L., 2015, p. 131). In fact, the introduction of the computer in school doesn't just represent an element of well-needed modernization or a new and indispensable field of learning; it is set to radically change the relationships between the subjects involved, and between them and knowledge. The relationship between teacher and students and between students, the learning motivation, the teaching through problems, the personalized courses based on the learning styles and times of every single student: they're all destined to change and to radically affect the way we do school. (Mantovani S. \& Ferri P., 2008, p. 144).

Preschool has to deal with this revolution too; it has to ponder what role to play in order to promote, critically mediate and sometimes facilitate its discovery and use. Here children are faced with these new communication languages both as a spectator and as an actor; therefore, school has to help them familiarize with the digital communication and multimedia dimension, fostering a contact with it and with the active search for new expressive and creative possibilities through media. Digital technologies in school can't and shouldn't be an end in themselves (learned to be applied), but a means to better express certain contents and share them with others in an effective way. That is to say, they have to be used as a tool to learn and organize one's own knowledge. As in every other learning field, in the educational context we need to start from children's ideas and family experiences in order to know exactly the potential and the restrictions of the environment in which we move. Because of its unique characteristics, preschool allows us, more than other level of education, to avoid presenting computer science as an independent discipline, supporting its development from an instrumental and supplementary perspective, so that it can be used in all school settings. It's important to contextualize the new technologies to the single realities, starting from the problems, curiosities and activities coming from the direct experience of the children introduced to the computer. The student coming from preschool, specifically, should be able to explore the possibilities of technologies, in order to make use of the different artistic forms, to communicate through them and to experience the first forms of communication through writing, using technologies too. (Mantovani S. \& Ferri P., 2008, p. 70).

Hence, in these educational contexts, the computer can represent an additional resource to stimulate creativity and attention in learning processes. This ever-present digital environment and the total and continuous interaction with it have radically changed the way of thinking and processing information: compared to their predecessors, they develop hypertextual minds and different types of experiences generate different brain structures (parallel cognitive structures, not sequential) (Prensky M., 2001, p. 1). Through an investigation in 2000, Prensky proved the digital natives' multitasking abilities: five-year-old children could simultaneously play and receive important and interesting information from a video, keeping their attention without leaving anything behind. (Prensky M., 2001, p. 10). These subjects' cognitive differences require new and better teaching approaches. Prensky has discovered that videogames and computer games are one of the few structures capable to fulfil the learning needs of the digital natives. That's 
why the teaching partially based on digital games is starting to develop and take hold. The fact that some games don't generate learning isn't because they're games or because the concept of learning by playing is false, but because these games are poorly designed. There is a great deal of evidence showing that welldesigned learning games for children generate learning. (Prensky M., 2001, p. 10). The digital tools create non-competitive, cooperative and collaborative approaches, as shown by Gilbert e Yelland (2014): very often the more competent student helps the less competent one by suggesting the best strategy to use a certain function in a sort of spontaneous peer tutoring process. By observing how freely they explore, communicate, discover and exchange information through the new technologies, not in isolation but by physically touching and looking at each other, preschool has the time to think, discuss and allow its students to master the tools and not to depend on them. (Mantovani S. \& Ferri P., 2008, p. XXI).

Pre-school exposure to a precocious and extended digital technology causes both positive and negative effects (Bozzola E. et al., 2018, p. 1); the positive aspects mainly lie in the education and cognitive fields, while the negative aspects mainly lie in the physical, psychological and social domains. (Wu C. et al., 2014, p. 1).

According to many experts, evaluating the type of technology or software to use is important to analyse the relationship between digital technologies and attention. No drop of attention or performance is produced if children use writing and calculation programs, peer communication and cooperation programs or even adventure videogames which imply the construction of scenarios, situations and possible worlds; actually, they often improve. On the contrary, we witness a considerable drop of cognitive performance if children use repetitive videogames at length or use technology and computers to isolate themselves from their peers and families in a stereotypical way (Garassini S. \& Romano G, 2001, p. 43). So, if the use of technology is stereotypical and marginalizing, it is very easily relatable to a reduction of the attention span; while, if the digital activity fosters social and communicative relationships or the learning processes, the attention isn't negatively affected but actually stimulated. (Mantovani S. \& Ferri P., 2008, p. 78).

Digital media have made communication easier, faster and more immediate, but this computer mediated communication lacks the paralinguistic elements of face-to-face conversation. It also lacks the feedback which allows the interlocutors to precisely identify the relational and social aspects. (Sproull \& Kiesler, 1986) (Radice G., 2017, p. 4). This change concerns individuals of all ages and cultures. This revolution has hit preschool too, mainly by changing the non-verbal communication aspects. Proxemics, for example, presents blurred areas: preschool children, by interacting with a digital device, allow their teachers and peers to enter their intimate space, which doesn't always happen without devices. This is possible because children of this age are fascinated by what the display delivers (colours, actions, characters...) and keep the technological device at a short and almost intimate distance.

For what concerns posture, demonizing technology is absolutely useless because the problem is in how we misuse it; digital natives use these devices from the pre-school age, which is the main physical bone and muscular growth phase. This extended and relaxed use, paired with a wrong posture, generates several back, neck and hand problems. However, educating children in keeping a right posture is crucial; the display has to be at eye height, so that they don't bend the neck forward and overload the spine in the cervical region; the back has to be straight and reclined and the feet should be planted firmly on the ground. Both parents at home and teachers in school need to instil these good habits. (Manca M., 2015, p. 1). Therefore, preschool has to find an optimal computer position in order to make students naturally take the right posture. Finally, digital communication influences pre-school children's sentimental and emotional spheres; they express the same emotions related to what happens on the digital screen. The emotional contagion is unconscious and 
based on the non-verbal elements sent from the characters. The people who are predisposed to these "social viruses" tend to reproduce facial and vocal expressions, postures and behaviours of those surrounding them (or of the most present characters in mass media) in order to "catch" the emotions provoked by those characters. (Manca M., 2015, p. 1).

The figure of the teacher has evolved through technology too: this metamorphosis implies that the child is at the centre as a protagonist; it also implies the need to take into consideration different social, ethnological and anthropological contexts, with the use of completely new interaction and cooperation digital tools. Moreover, it entails a more active role for teachers who, from being "masters of the classroom" and handing out knowledge, become didactic architects, guides and trainers to a small team of talents. Thus, we are rapidly shifting from a one-many/transmissive didactic model to a many-many/cooperative one, where the role of the teacher and the taught acquire a variable geometry, according to the present or virtual setting adopted. (Mantovani S. \& Ferri P., 2008, p. 41). All these changes, improvements and updates are possible only if the teachers get adequately trained: this training doesn't concern the instructions on how to use tools, but the professional awareness; it aims at comforting, reducing the anxiety and the feeling of inadequacy. (Vayola P., 2016, p. 184). By feeling more confident, teachers will enrich and extend the experiential spaces; together with the students, they will create equilibrate learning environments where the "new" isn't excluded and where all languages can be accepted and integrated, building meaningful citizenship skills. (Vayola P., 2016, p. 188).

For this reason, the objective of this investigation was to analyse elements of digital and non-verbal communication related to preschool children and everything surrounding them.

\section{MATERIALS AND METHODS}

This research has tried to analyse the present situation of learners in preschool age (age 3-5), focusing on non-verbal and digital communication aspects in the preschool dynamics. Online databases (such as EBSCO, Google Schoolar, PubMed, Urbls), personal libraries and government documents have been used for relevant studies. A total of 36 papers divided in 20 articles, 16 international pieces of research and 4811 participants, have complied with the inclusion criteria. The inclusion indicators were:

Non-verbal communication aspects

Digital communication aspects

The school itself (pupils, teachers, principals, parents), mainly the preschool.

\section{RESULTS}

In ascending order, Table 2 shows the descriptive characteristics of all the international articles taken into consideration for the research. It contains:

- 3 papers of 2018 (two of them are Spanish, one is Australian),

- 4 of 2017 (two Americans, two Italians),

- 11 of 2016 (seven Americans, 2 Italians, 1 Maltese, 1 Norwegian),

- 3 of 2015 (2 Australians, one American),

- 5 of 2015 (one American, one Australian, one Chinese and one Dutch), 
- 2 Italian papers of 2013, an American one of 2011, a Swedish one from 2009; two American papers from 2003 and 2001,

- A Spanish article from 2000 and 2 articles from 1994 (one American and one German).

Table 2. International research papers: descriptive characteristics

\begin{tabular}{|c|c|c|c|c|c|c|}
\hline TITLE & AUTHORS & $\begin{array}{l}\text { YEAR } \\
\text { COUNTRY }\end{array}$ & $\begin{array}{l}\text { SEARCH ENGINE } \\
\text { PERIODI-CAL }\end{array}$ & SETTING & $\begin{array}{l}\text { ACTIVITIES } \\
\text { and } \\
\text { MATERIALS }\end{array}$ & RESULTS \\
\hline $\begin{array}{l}\text { Learning across } \\
\text { Settings and Time } \\
\text { in the Digital Age }\end{array}$ & $\begin{array}{l}\text { M. Esteban- } \\
\text { Guitart } \\
\text { C. Coll } \\
\text { W. Penuel }\end{array}$ & Spain & $\begin{array}{l}\text { Ebsco } \\
\text { digitalEDU-CATION }\end{array}$ & & & \\
\hline $\begin{array}{l}\text { "The internet is all } \\
\text { around us": How } \\
\text { children come to } \\
\text { understand the } \\
\text { Internet }\end{array}$ & $\begin{array}{l}\text { T. Murray } \\
\text { R. Buchanan }\end{array}$ & 2018 & $\begin{array}{l}\text { Ebsco } \\
\text { Digital Culture \& } \\
\text { Education (DCE) }\end{array}$ & $\begin{array}{l}33 \text { children age } \\
10-11 \\
\text { Primary school }\end{array}$ & $\begin{array}{l}\text { This study } \\
\text { analyses } \\
\text { through } \\
\text { interviews } \\
\text { and drawings, } \\
\text { how children } \\
\text { develop their } \\
\text { knowledge of } \\
\text { the Internet } \\
\text { and their } \\
\text { online } \\
\text { behaviour }\end{array}$ & $\begin{array}{l}\text { Children enjoy } \\
\text { surfing on the } \\
\text { Internet in all its } \\
\text { aspects; they } \\
\text { own a wide } \\
\text { range of digital } \\
\text { devices. They } \\
\text { are also } \\
\text { worried about } \\
\text { cyberbullying, } \\
\text { addiction, } \\
\text { privacy and } \\
\text { online } \\
\text { predators }\end{array}$ \\
\hline $\begin{array}{l}\text { Young people's } \\
\text { learning } \\
\text { trajectories in the } \\
\text { digital age }\end{array}$ & R. Mino & $\begin{array}{l}2018 \\
\text { Spain }\end{array}$ & $\begin{array}{l}\text { Ebsco } \\
\text { digital EDUCATION }\end{array}$ & $\begin{array}{l}34 \text { children of } \\
\text { mixed age } \\
\text { Preschool and } \\
\text { Primary school }\end{array}$ & $\begin{array}{l}\text { f This research } \\
\text { investigates } \\
\text { through } \\
\text { workshops } \\
\text { and } \\
\text { storytelling, } \\
\text { children's } \\
\text { learning } \\
\text { experiences } \\
\text { in and outside } \\
\text { the school } \\
\text { environment }\end{array}$ & $\begin{array}{l}\text { Children learn } \\
\text { through events } \\
\text { and contexts } \\
\text { but the digital } \\
\text { media promote } \\
\text { learning the } \\
\text { most. }\end{array}$ \\
\hline $\begin{array}{l}\text { Bidirectional } \\
\text { Linkages } \\
\text { Between Emotion } \\
\text { Recognition } \\
\text { and Problem } \\
\text { Behaviors in } \\
\text { Elementary } \\
\text { School Children }\end{array}$ & $\begin{array}{l}\text { V. L. Castro } \\
\text { A. N. Cooke } \\
\text { A.G. } \\
\text { Halberstadt } \\
\text { P. G. Peters } \\
\end{array}$ & 2017 & $\begin{array}{l}\text { Urbis } \\
\text { Springer-Link } \\
\text { Journal of } \\
\text { Nonverbal Behavior }\end{array}$ & $\begin{array}{l}117 \text { children age } \\
6-8 \\
\text { Primary school } \\
r\end{array}$ & $\begin{array}{l}\text { This study } \\
\text { examines } \\
\text { through } \\
\text { images, the } \\
\text { relationship } \\
\text { between } \\
\text { emotional } \\
\text { awareness } \\
\text { and } \\
\text { problematic } \\
\text { behaviours }\end{array}$ & $\begin{array}{l}\text { The failure to } \\
\text { recognize } \\
\text { emotions leads } \\
\text { children to } \\
\text { problematic } \\
\text { and abnormal } \\
\text { behaviours; on } \\
\text { the contrary, } \\
\text { the presence of } \\
\text { the latter } \\
\text { doesn't }\end{array}$ \\
\hline
\end{tabular}




\begin{tabular}{|c|c|c|c|c|c|}
\hline & & & & & $\begin{array}{l}\text { influence the } \\
\text { former }\end{array}$ \\
\hline $\begin{array}{l}\text { Non-verbal } \\
\text { communication. } \\
\text { Functions and } \\
\text { characteristics }\end{array}$ & F. Maricchiolo & 2017 & $\begin{array}{l}\text { Google } \\
\text { The Inquisitive Mind }\end{array}$ & & \\
\hline $\begin{array}{l}\text { Non-verbal } \\
\text { behavior in the } \\
\text { digital age: } \\
\text { meanings, } \\
\text { models and } \\
\text { methods }\end{array}$ & J. Montepare & 2017 & $\begin{array}{l}\text { Ebsco } \\
\text { Springer } \\
\text { Journal of } \\
\text { Nonverbal Behavior }\end{array}$ & & \\
\hline $\begin{array}{l}\text { Digital School, it's } \\
\text { time to have } 4.0 \\
\text { Google and } \\
\text { Microsoft } \\
\text { competences }\end{array}$ & F. Meta & $\begin{array}{l}2017 \\
\text { Italy }\end{array}$ & $\begin{array}{l}\text { Google } \\
\text { COR.COM }\end{array}$ & & \\
\hline $\begin{array}{l}\text { Can computers } \\
\text { foster human } \\
\text { users' creativity? } \\
\text { Theory and praxis } \\
\text { of mixed-initiative } \\
\text { co-creativity }\end{array}$ & $\begin{array}{l}\text { A. Liapis } \\
\text { G. Yannakakis } \\
\text { C. Alexopoulos } \\
\text { P. Lopes }\end{array}$ & $\begin{array}{l}2016 \\
\text { Malta }\end{array}$ & $\begin{array}{l}\text { Ebsco } \\
\text { Digital Culture \& } \\
\text { Education (DCE) }\end{array}$ & & \\
\hline $\begin{array}{l}\text { Children's } \\
\text { Nonverbal } \\
\text { Displays of } \\
\text { Winning and } \\
\text { Losing: Effects of } \\
\text { Social and } \\
\text { Cultural Contexts } \\
\text { on Smiles }\end{array}$ & $\begin{array}{l}\text { P. H. C. Mui, } \\
\text { B. Goudbeek, } \\
\text { M. G. J. Swerts, } \\
\text { A. Hovasapian }\end{array}$ & $\begin{array}{l}2016 \\
\text { America }\end{array}$ & $\begin{array}{l}\text { Urbis } \\
\text { SpringerLink } \\
\text { Journal of } \\
\text { Nonverbal Behavior }\end{array}$ & $\begin{array}{l}86 \text { children age } \\
8 \text { ( } 55 \text { Chinese } \\
\text { and } 31 \text { Dutch) } \\
\text { Primary school }\end{array}$ & 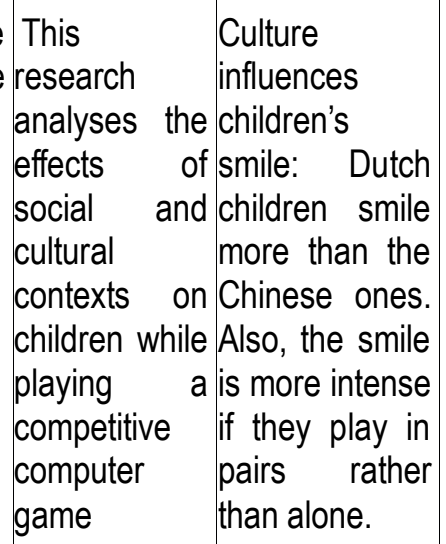 \\
\hline $\begin{array}{l}\text { Eye behavior and } \\
\text { gaze }\end{array}$ & $\begin{array}{l}\text { R. Adams Jr. } \\
\text { A. Nelson }\end{array}$ & $\begin{array}{l}2016 \\
\text { America }\end{array}$ & $\begin{array}{l}\text { Ebsco } \\
\text { APA handbook of } \\
\text { nonverbal } \\
\text { communication }\end{array}$ & & \\
\hline $\begin{array}{l}\text { Facial } \\
\text { Expressions }\end{array}$ & $\begin{array}{l}\text { D. Matsumoto } \\
\text { H. Hwang }\end{array}$ & $\begin{array}{l}2016 \\
\text { America }\end{array}$ & $\begin{array}{l}\text { Ebsco } \\
\text { APA handbook of } \\
\text { nonverbal } \\
\text { communication }\end{array}$ & & \\
\hline Gesture & $\begin{array}{l}\text { E. Cartmill } \\
\text { S. Goldin- }\end{array}$ & $\begin{array}{l}2016 \\
\text { America }\end{array}$ & Ebsco & & \\
\hline
\end{tabular}




\begin{tabular}{|c|c|c|c|c|c|c|}
\hline & Meadow & & $\begin{array}{l}\text { APA handbook of } \\
\text { nonverbal } \\
\text { communication }\end{array}$ & & & \\
\hline $\begin{array}{l}\text { Risks and } \\
\text { Opportunities of } \\
\text { the Digital School. } \\
\text { Cues for teacher } \\
\text { training }\end{array}$ & P. Vayola & $\begin{array}{l}2016 \\
\text { Italy }\end{array}$ & $\begin{array}{l}\text { Form@are } \\
\begin{array}{l}\text { Open Journal per la } \\
\text { formazione in rete }\end{array}\end{array}$ & & & \\
\hline $\begin{array}{l}\text { Verbal and Non- } \\
\text { verbal } \\
\text { Languages. } \\
\text { Problems } \\
\text { Intercultural } \\
\text { Communication in } \\
\text { German-speaking } \\
\text { Countries }\end{array}$ & $\begin{array}{l}\text { M. } \\
\text { Vecchia }\end{array}$ & $\begin{array}{l}2016 \\
\text { Italy }\end{array}$ & $\begin{array}{l}\text { Google Scholar } \\
\text { EL.LE }\end{array}$ & & & \\
\hline $\begin{array}{l}\text { Self-reported } \\
\text { quality of life and } \\
\text { self-esteem in sad } \\
\text { and anxious } \\
\text { school children }\end{array}$ & $\begin{array}{l}\text { K. D. Martinsen, } \\
\text { S. Neumer, } \\
\text { S. Holen, } \\
\text { T. Waaktaar, } \\
\text { A. M. Sund, } \\
\text { P. C. Kendal }\end{array}$ & Norway & $\begin{array}{l}\mathrm{NBCl} \\
\mathrm{PMC} \\
\mathrm{BMC} \text { Psychology }\end{array}$ & $\begin{array}{l}915 \text { children age } \\
9-12 \\
\text { Primary } \\
\text { school }\end{array}$ & $\begin{array}{l}\text { This study } \\
\text { examines the } \\
\text { stress } \\
\text { (MASC-C } \\
\text { scale), } \\
\text { depression } \\
\text { level (B-SCl- } \\
\text { Y) and quality a } \\
\text { of life levels of } \\
\text { Norwegian } \\
\text { children }\end{array}$ & $\begin{array}{l}\text { Examined } \\
\text { children } \\
\text { showed } \\
\text { anxiety and } \\
\text { depression } \\
\text { symptoms. The } \\
\text { former can also } \\
\text { affect other } \\
\text { specific } \\
\text { domains but it } \\
\text { can't influence } \\
\text { the quality of } \\
\text { life in the same } \\
\text { way as } \\
\text { depression } \\
\text { symptoms do. }\end{array}$ \\
\hline $\begin{array}{lc}\text { The } & \text { body: } \\
\text { postures, } & \text { gait, } \\
\text { proxemics } & \text { and } \\
\text { haptics } & \end{array}$ & $\begin{array}{l}\text { D. Matsumoto } \\
\text { H. Hwang } \\
\text { M. Frank }\end{array}$ & $\begin{array}{l}2016 \\
\text { America }\end{array}$ & $\begin{array}{l}\text { Ebsco } \\
\text { APA handbook of } \\
\text { nonverbal } \\
\text { communication }\end{array}$ & & & \\
\hline $\begin{array}{l}\text { The cultural } \\
\text { bases of } \\
\text { nonverbal } \\
\text { communication }\end{array}$ & $\begin{array}{l}\text { D. Matsumoto } \\
\text { H. Hwang }\end{array}$ & $\begin{array}{l}2016 \\
\text { America }\end{array}$ & $\begin{array}{l}\text { Ebsco } \\
\text { APA handbook of } \\
\text { nonverbal } \\
\text { communication }\end{array}$ & & & \\
\hline $\begin{array}{l}\text { The physical } \\
\text { environment and } \\
\text { nonverbal } \\
\text { communication }\end{array}$ & $\begin{array}{l}\text { M. Patterson } \\
\text { S. Quadflieg }\end{array}$ & $\begin{array}{l}2016 \\
\text { America }\end{array}$ & $\begin{array}{l}\text { Ebsco } \\
\text { APA handbook of } \\
\text { nonverbal } \\
\text { communication }\end{array}$ & & & \\
\hline Educating & T. Cinque & 2015 & Ebsco & university 7 & This research & Students \\
\hline
\end{tabular}




\begin{tabular}{|c|c|c|c|c|c|}
\hline $\begin{array}{lr}\text { generation } & \text { next: } \\
\text { screen } & \text { media } \\
\text { use, } & \text { digital } \\
\text { competencies } \\
\text { and } & \text { tertiary } \\
\text { education } & \end{array}$ & A. Brown & Australia & $\begin{array}{l}\text { Digital Culture \& } \\
\text { Education (DCE) }\end{array}$ & $\&$ students & \begin{tabular}{l|l|l} 
investigates & the Internet \\
the new & every day, \\
media & mainly for \\
perception & recreational \\
and usage by & purposes and \\
interviewing for \\
university & entertainment; \\
students: & they also use it \\
what's their to study and \\
digital skills? work, albeit at a \\
Do they use lesser \\
the Internet to percentage. \\
study, work or \\
create web \\
pages?
\end{tabular} \\
\hline $\begin{array}{l}\text { Generic reference } \\
\text { is less } \\
\text { than marked } \\
\text { referencer in } \\
\text { children's gesture }\end{array}$ & $\begin{array}{l}\text { M. Meyer } \\
\text { S. Gelman }\end{array}$ & $\begin{array}{l}2015 \\
\text { America }\end{array}$ & $\begin{array}{l}\text { Ebsco } \\
\text { Springer } \\
\text { Journal of } \\
\text { Nonverbal Behavior }\end{array}$ & $\begin{array}{l}24 \text { children (12 } \\
\text { age3- 4; } 12 \text { age } \\
5-6) \\
\text { of Nurse school } \\
\text { or } \\
\end{array}$ & \begin{tabular}{l|l} 
This study & Children, like \\
examines & adults, tend to \\
through & gesticulate \\
animal & while using \\
pictures, how & specific \\
children & sentences \\
gesticulate & rather than \\
according to generic ones \\
generic or & \\
specific & \\
sentences &
\end{tabular} \\
\hline $\begin{array}{l}\text { Teaching in an } \\
\text { age of ubiquitous } \\
\text { computing: } \mathrm{A} \\
\text { decelerated } \\
\text { curriculum }\end{array}$ & & $\begin{array}{l}2015 \\
\text { Australia }\end{array}$ & $\begin{array}{l}\text { Ebsco } \\
\text { Digital Culture \& } \\
\text { Education (DCE) }\end{array}$ & & \\
\hline $\begin{array}{l}\text { Contextual effects } \\
\text { on surprise } \\
\text { expressions: a } \\
\text { development } \\
\text { study }\end{array}$ & $\begin{array}{l}\text { M. Visser } \\
\text { E. Krahmer } \\
\text { M. Swerts }\end{array}$ & $\begin{array}{l}2014 \\
\text { Holland }\end{array}$ & $\begin{array}{l}\text { Ebsco } \\
\text { Springer } \\
\text { Journal } \\
\text { Nonverbal Behavior }\end{array}$ & $\begin{array}{l}90 \text { children (42 } \\
\text { of } 8 \text { years old } \\
\text { and } 48 \text { of } 11 \\
\text { of years old) } \\
\text { or Primary school }\end{array}$ & \begin{tabular}{l|l} 
This research Children show \\
examines & surprise when \\
through a they are in \\
computer & competitive \\
quiz, causes, & and negative \\
social & contexts rather \\
contexts and than in \\
ages that \\
influence the collaborative \\
non-verbal \\
expression of \\
surprise.
\end{tabular} \\
\hline $\begin{array}{l}\text { Digital culture and } \\
\text { neuroscience: A } \\
\text { conversation with } \\
\text { learning and } \\
\text { curriculum }\end{array}$ & $\begin{array}{l}\text { K. Grushka } \\
\text { D. Donnelly } \\
\text { N. Clement }\end{array}$ & $\begin{array}{l}2014 \\
\text { Australia }\end{array}$ & $\begin{array}{l}\text { Ebsco } \\
\text { Digital Culture } \\
\text { Education (DCE) }\end{array}$ & & \\
\hline
\end{tabular}




\begin{tabular}{|c|c|c|c|c|c|c|}
\hline $\begin{array}{lr}\text { Learning } & \text { to } \\
\text { leisure? When } \\
\text { social media } \\
\text { becomes } \\
\text { educational } \\
\text { media }\end{array}$ & T. Brabazon & $\begin{array}{l}2014 \\
\text { Australia }\end{array}$ & $\begin{array}{l}\text { Ebsco } \\
\text { Digital Culture \& } \\
\text { Education (DCE) }\end{array}$ & & & \\
\hline $\begin{array}{l}\text { Nonverbal } \\
\text { behavior in the } \\
\text { digital age: } \\
\text { explorations in } \\
\text { internet social } \\
\text { communication }\end{array}$ & J. Montepare & $\begin{array}{l}2014 \\
\text { America }\end{array}$ & $\begin{array}{l}\text { Ebsco } \\
\text { Springer } \\
\text { Journal of } \\
\text { Nonverbal Behavior }\end{array}$ & & & \\
\hline $\begin{array}{l}\text { Parenting } \\
\text { approaches and } \\
\text { digital technology } \\
\text { use of preschool } \\
\text { age children in a } \\
\text { Chinese } \\
\text { community }\end{array}$ & $\begin{array}{l}\text { C. Sau Ting Wu, } \\
\text { C. Fowler, } \\
\text { W. Yuk Yin Lam, } \\
\text { H. Ting Wong, } \\
\text { C. Hei Man } \\
\text { Wong, } \\
\text { A. Yuen Loke }\end{array}$ & China & $\begin{array}{l}\text { NCBI } \\
\text { PMC } \\
\text { Italian Journal of } \\
\text { Pediatrics }\end{array}$ & $\begin{array}{l}202 \text { parents } \\
\text { children } \\
\text { Preschool } \\
\end{array}$ & $\begin{array}{l}\text { of This study } \\
\text { in analyses } \\
\text { parenting } \\
\text { approaches } \\
\text { to their } \\
\text { children's use } \\
\text { of digital } \\
\text { technology; it } \\
\text { also } \\
\text { examines the } \\
\text { relationship } \\
\text { between } \\
\text { these the } \\
\text { approaches } \\
\text { and } \\
\text { development } \\
\text { of } \\
\text { problematic } \\
\text { behaviours in } \\
\text { children. A } \\
\text { survey has } \\
\text { been carried } \\
\text { out. }\end{array}$ & $\begin{array}{l}\text { Results } \\
\text { showed that } \\
\text { parents } \\
\text { influence their } \\
\text { children's use } \\
\text { of the digital } \\
\text { technology. } \\
\text { The preferred } \\
\text { approach is } \\
\text { represented by } \\
\text { the } \\
\text { combination of } \\
\text { three } \\
\text { approaches. } \\
\text { Children } \\
\text { develop } \\
\text { behavioural } \\
\text { problems if } \\
\text { they aren't } \\
\text { closely } \\
\text { followed by } \\
\text { their parents } \\
\text { and if they } \\
\text { overuse the } \\
\text { digital media. }\end{array}$ \\
\hline $\begin{array}{l}\text { Communication } \\
\text { between School } \\
\text { and Families: } \\
\text { Educational } \\
\text { Institution seem to } \\
\text { be Aware of the } \\
\text { Importance of } \\
\text { Technology but } \\
\text { Prefer less } \\
\text { Interactive } \\
\text { Instruments }\end{array}$ & $\begin{array}{l}\text { BMP } \\
\text { Comunicazione } \\
\text { per Kion } \\
\text { (P. Barrile } \\
\text { M. Mantegazza } \\
\text { F. Petrella) } \\
\end{array}$ & $\begin{array}{l}2013 \\
\text { Italy }\end{array}$ & $\begin{array}{l}\text { Edscuola } \\
\text { Giunti scuola }\end{array}$ & $\begin{array}{l}420 \text { principals } \\
\text { Nursey, Prima } \\
\text { and Seconda } \\
\text { school }\end{array}$ & $\begin{array}{l}\text { of This study } \\
\text { ary aims at } \\
\text { ary monitoring } \\
\text { and analysing } \\
\text { setting and } \\
\text { applications } \\
\text { of modern } \\
\text { technologies } \\
\text { in the } \\
\text { educational } \\
\text { system }\end{array}$ & $\begin{array}{l}\text { The use of } \\
\text { digital } \\
\text { technology is } \\
\text { still limited in } \\
\text { terms of means } \\
\text { and } \\
\text { accessibility to } \\
\text { the available } \\
\text { potential }\end{array}$ \\
\hline Digital & N. Olivieri & 2013 & Google Scholar & & & \\
\hline
\end{tabular}




\begin{tabular}{|c|c|c|c|c|c|c|}
\hline Revolution Impact & P. Ferri & Italy & Novecento.org & & & \\
\hline $\begin{array}{l}\text { Representational } \\
\text { gesture, pointing } \\
\text { gesture and } \\
\text { memory recall of } \\
\text { preschool } \\
\text { children }\end{array}$ & $\begin{array}{l}\text { H. Cameron } \\
\text { X. Xu }\end{array}$ & $\begin{array}{l}2011 \\
\text { America }\end{array}$ & $\begin{array}{l}\text { Ebsco } \\
\text { Springer } \\
\text { Journal of } \\
\text { Nonverbal Behavior }\end{array}$ & $\begin{array}{l}30 \text { children from } \\
48-63 \text { months }\end{array}$ & $\begin{array}{l}\text { This study } \\
\text { investigates } \\
\text { the effects of } \\
\text { two different } \\
\text { gestures in } \\
\text { relation to } \\
\text { children's } \\
\text { memory }\end{array}$ & $\begin{array}{l}\text { Children tend } \\
\text { to recall and } \\
\text { provide more } \\
\text { information } \\
\text { when they } \\
\text { gesticulate } \\
\text { during the } \\
\text { conversation }\end{array}$ \\
\hline $\begin{array}{l}\text { The emotional } \\
\text { body } \\
\text { relationship in }\end{array}$ & F. Battista & $\begin{array}{l}2010 \\
\text { Italy }\end{array}$ & $\begin{array}{l}\text { ResearchGate } \\
\text { Nuoveartiterapie }\end{array}$ & & & \\
\hline $\begin{array}{l}\text { Not so "techno- } \\
\text { savvy": } \\
\text { Challenging the } \\
\text { stereotypical } \\
\text { images of the Net } \\
\text { generation }\end{array}$ & S. Zimic & $\begin{array}{l}2009 \\
\text { Sweden }\end{array}$ & $\begin{array}{l}\text { Ebsco } \\
\text { Digital, Culture \& } \\
\text { Education (DCE) }\end{array}$ & $\begin{array}{l}2266 \\
\text { studentsage12- } \\
30\end{array}$ & $\begin{array}{l}\text { This research } \\
\text { wants to } \\
\text { compare the } \\
\text { results of the } \\
\text { interview } \\
\text { about Internet } \\
\text { skills, with the } \\
\text { stereotypes } \\
\text { regarding } \\
\text { digital } \\
\text { natives, } \\
\text { technology } \\
\text { experts }\end{array}$ & $\begin{array}{l}\text { The main } \\
\text { conclusions } \\
\text { drawn from the } \\
\text { results are: it's } \\
\text { too easy to talk } \\
\text { about a "net } \\
\text { generation"; } \\
\text { many of the } \\
\text { stereotypes } \\
\text { about the "net } \\
\text { generation" } \\
\text { can fade; we } \\
\text { can't talk about } \\
\text { a } \\
\text { generation" } \\
\text { only } \\
\text { considering the } \\
\text { birth year of the } \\
\text { subjects; their } \\
\text { competences } \\
\text { are crucial too. }\end{array}$ \\
\hline $\begin{array}{l}\text { Do actions speak } \\
\text { louder than } \\
\text { words? Preschool } \\
\text { children's use of } \\
\text { the verbal- } \\
\text { nonverbal } \\
\text { consistency } \\
\text { principle during } \\
\text { inconsistent } \\
\text { communication }\end{array}$ & $\begin{array}{l}\text { M. Eskritt } \\
\text { K. Lee }\end{array}$ & $\begin{array}{l}2003 \\
\text { America }\end{array}$ & $\begin{array}{l}\text { Ebsco } \\
\text { Springer } \\
\text { Journal of } \\
\text { Nonverbal Behavior }\end{array}$ & $\begin{array}{l}91 \text { children (33 } \\
\text { age } 3 ; 28 \text { age 4; } \\
30 \text { age } 5) \\
\text { Preschool }\end{array}$ & $\begin{array}{l}\text { This study } \\
\text { investigates } \\
\text { whether } \\
\text { children pay } \\
\text { more } \\
\text { attention to } \\
\text { verbal cues } \\
\text { than to non- } \\
\text { verbal ones } \\
\text { when they are } \\
\text { in contrast }\end{array}$ & $\begin{array}{l}\text { Non-verbal } \\
\text { cues prevail on } \\
\text { verbal ones } \\
\text { only if they are } \\
\text { exaggerated, } \\
\text { unnatural }\end{array}$ \\
\hline $\begin{array}{l}\text { Digital Natives, } \\
\text { Digital Immigrants }\end{array}$ & M. Prensky & $\begin{array}{l}2001 \\
\text { America }\end{array}$ & University & & & \\
\hline
\end{tabular}




\begin{tabular}{|c|c|c|c|c|c|c|}
\hline & & & Press & & & \\
\hline $\begin{array}{l}\text { Looking behavior } \\
\text { and smiling } \\
\text { in down syndrome } \\
\text { infants }\end{array}$ & $\begin{array}{l}\text { F. Carvajal, } \\
\text { J. Iglesias }\end{array}$ & $\begin{array}{l}2000 \\
\text { Spain }\end{array}$ & $\begin{array}{l}\text { Urbis } \\
\text { SpringerLink } \\
\text { Journal of } \\
\text { Nonverbal Behavior }\end{array}$ & $\begin{array}{l}30 \text { children (and } \\
\text { their mothers); } \\
15 \text { of them have } \\
\text { Preschool }\end{array}$ & $\begin{array}{l}\text { This study } \\
\text { compares the } \\
\text { development } \\
\text { of smile and } \\
\text { eye gaze in } \\
\text { neurotypical } \\
\text { children and } \\
\text { with Down } \\
\text { syndrome }\end{array}$ & $\begin{array}{l}\text { Mothers of both } \\
\text { groups of } \\
\text { children } \\
\text { behave } \\
\text { equally. } \\
\text { Children } \\
\text { d interact the } \\
\text { most with their } \\
\text { mothers rather } \\
\text { than with the } \\
\text { object; they } \\
\text { look at their } \\
\text { mother's face }\end{array}$ \\
\hline $\begin{array}{lr}\text { Display rule } \\
\text { behavior and } \\
\text { understanding in } \\
\text { preschool } \\
\text { children }\end{array}$ & & $\begin{array}{l}1994 \\
\text { Germany }\end{array}$ & $\begin{array}{l}\text { Ebsco } \\
\text { Journal of } \\
\text { Nonverbal Behavior }\end{array}$ & $\begin{array}{l}72 \text { children age } \\
4 \\
\text { Preschool }\end{array}$ & $\begin{array}{l}\text { This research } \\
\text { investigates } \\
\text { whether } \\
\text { children } \\
\text { understand } \\
\text { the difference } \\
\text { between real } \\
\text { and apparent } \\
\text { emotions in } \\
\text { tales }\end{array}$ & $\begin{array}{l}\text { Female } \\
\text { children } \\
\text { understand } \\
\text { better the } \\
\text { difference } \\
\text { between real } \\
\text { and fake } \\
\text { and emotions. } \\
\text { Children } \\
\text { understand } \\
\text { more negative } \\
\text { emotions than } \\
\text { positive } \\
\text { emotions }\end{array}$ \\
\hline $\begin{array}{l}\text { Children's facial } \\
\text { and gestural } \\
\text { decoding and } \\
\text { encoding: } \\
\text { relations between } \\
\text { skills and with } \\
\text { popularity }\end{array}$ & $\begin{array}{l}\text { C. Boyatzis } \\
\text { C. Satyaprasad }\end{array}$ & $\begin{array}{l}1994 \\
\text { America }\end{array}$ & $\begin{array}{l}\text { Ebsco } \\
\text { Journal of } \\
\text { Nonverbal Behavior }\end{array}$ & $\begin{array}{l}34 \text { children (18 } \\
\text { age } 4 \text { and } 16 \\
\text { fage 5) } \\
\text { Preschool }\end{array}$ & $\begin{array}{l}\text { This study } \\
\text { examines } \\
\text { children's } \\
\text { ability to } \\
\text { encode and } \\
\text { decode facial } \\
\text { expressions } \\
\text { and gestures. } \\
\text { The } \\
\text { relationship } \\
\text { between this } \\
\text { ability and } \\
\text { popularity is } \\
\text { also } \\
\text { examined }\end{array}$ & $\begin{array}{l}\text { Children's } \\
\text { ability to } \\
\text { decode is } \\
\text { higher than the } \\
\text { encoding skill; } \\
\text { moreover, they } \\
\text { recognize } \\
\text { more facial } \\
\text { emotions than } \\
\text { gestures }\end{array}$ \\
\hline
\end{tabular}

Source: own calculation.

As showed in Table 3, four of the thirty-six papers complied with the requirements; we therefore decided to analyse and delve into them.

The first study (2015) is based on the digital media usage, while the second one (2014) focuses on parenting 
approaches to the digital technology use of preschool age children; the third one (2003) deals with the use of facial expressions and gestures in pre-schoolers and the last one (1994) concerns the verbal and nonverbal coherence principle at the age of 4 or 5 .

Table 3. Characteristics of the four studies

\begin{tabular}{|c|c|c|c|c|c|c|}
\hline TITLE & AUTHO-RS & $\begin{array}{l}\text { YEAR } \\
\text { COUN- } \\
\text { TRY }\end{array}$ & $\begin{array}{l}\text { - SEARCH } \\
\text { ENGINE } \\
\text { - PERIODICAL }\end{array}$ & $\begin{array}{l}\text { COMMUNICA- } \\
\text { TION }\end{array}$ & $\begin{array}{l}\text { SETTING } \\
\text { ACTIVITIES }\end{array}$ & OBJECTIVES \\
\hline $\begin{array}{l}\text { Educating } \\
\text { generation next: } \\
\text { screen media } \\
\text { use, digital } \\
\text { competencies } \\
\text { and tertiary } \\
\text { education }\end{array}$ & $\begin{array}{l}\text { T. Cinque } \\
\text { A. Brown }\end{array}$ & 2015 & $\begin{array}{l}\text { - } \quad \text { Ebsco } \\
\text { - Digital Culture \& } \\
\text { Education (DCE) }\end{array}$ & $\begin{array}{l}\text { Digital } \\
\text { communication }\end{array}$ & $\begin{array}{l}367 \text { students } \\
\text { Interview }\end{array}$ & $\begin{array}{l}\text { This study } \\
\text { research the } \\
\text { university } \\
\text { students' } \\
\text { perception and } \\
\text { use of the new } \\
\text { media: what are } \\
\text { their digital } \\
\text { competences? } \\
\text { Do they use the } \\
\text { internet to study, } \\
\text { work or create } \\
\text { web pages? }\end{array}$ \\
\hline $\begin{array}{l}\text { Parenting } \\
\text { approaches and } \\
\text { digital technology } \\
\text { use of preschool } \\
\text { age children in a } \\
\text { Chinese } \\
\text { community }\end{array}$ & $\begin{array}{l}\text { C. S. T. Wu } \\
\text { C. Fowler } \\
\text { W. Y. Y. Lam } \\
\text { H. T. Wong } \\
\text { C. H. M. M. } \\
\text { Wong } \\
\text { A. Y. Loke }\end{array}$ & China & $\begin{array}{l}\text { - NCBI } \\
\text { PMC } \\
\text { - Italian Journal of } \\
\text { Pediatrics }\end{array}$ & $\begin{array}{l}\text { Digital } \\
\text { communication }\end{array}$ & $\begin{array}{l}202 \text { parents o } \\
\text { children in } \\
\text { Preschool } \\
\text { Survey, } \\
\text { questionnaire }\end{array}$ & $\begin{array}{l}\text { This research } \\
\text { examines the } \\
\text { parenting } \\
\text { approaches to } \\
\text { their children's } \\
\text { use of the digital } \\
\text { media; it also } \\
\text { examines the } \\
\text { relationship } \\
\text { bet1111ween } \\
\text { these } \\
\text { approaches and } \\
\text { the development } \\
\text { of problematic } \\
\text { behaviours in } \\
\text { their children. }\end{array}$ \\
\hline $\begin{array}{l}\text { Do actions speak } \\
\text { louder than } \\
\text { words? } \\
\text { Preschool } \\
\text { children's use of } \\
\text { the verbal and } \\
\text { non-verbal } \\
\text { consistency } \\
\text { principle during } \\
\text { inconsistent } \\
\text { communication }\end{array}$ & $\begin{array}{l}\text { M. Eskritt } \\
\text { K. Lee }\end{array}$ & 2003 & $\begin{array}{l}\text { - Ebsco } \\
\text { Springer } \\
\text { - Journal of } \\
\text { Nonverbal Behavior }\end{array}$ & $\begin{array}{l}\text { Non-verbal } \\
\text { communication }\end{array}$ & $\begin{array}{l}91 \text { children (33 } \\
\text { age } 3 ; 28 \text { age } \\
4 ; 30 \text { age } 5) \\
\text { Preschool } \\
\text { Video }\end{array}$ & $\begin{array}{l}\text { This study } \\
\text { investigates } \\
\text { whether children } \\
\text { pay more } \\
\text { attention to } \\
\text { verbal cues than } \\
\text { to non-verbal } \\
\text { ones when they } \\
\text { are in contrast }\end{array}$ \\
\hline
\end{tabular}




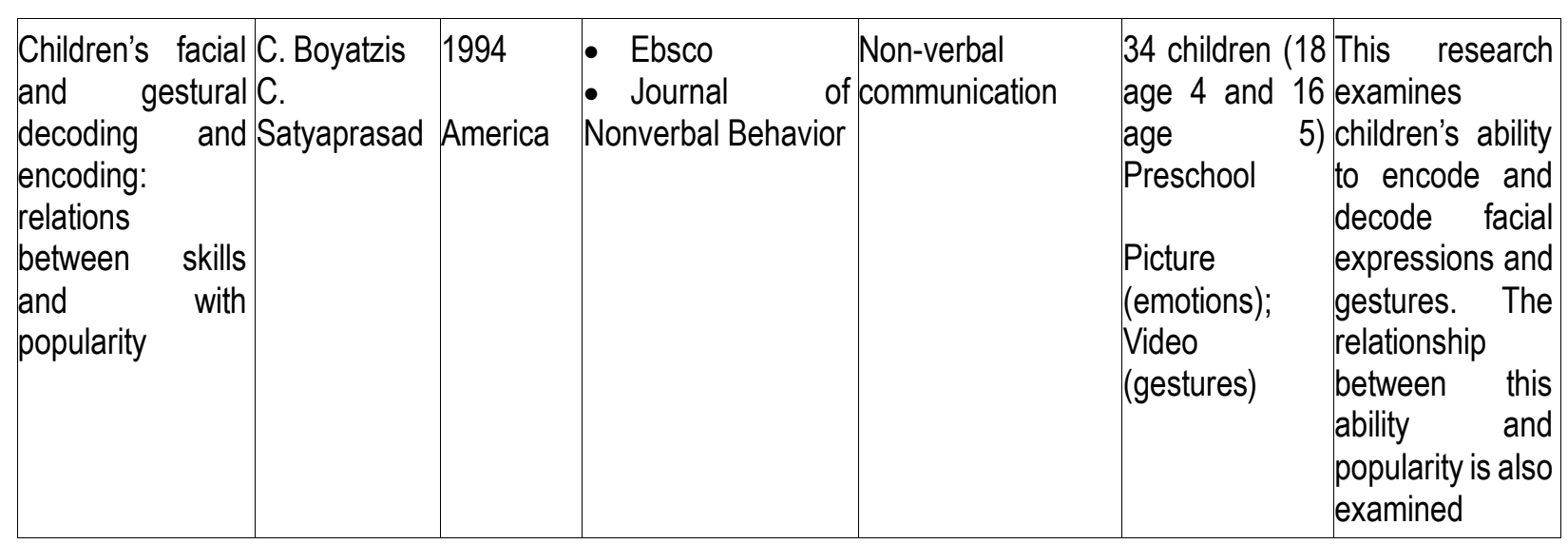

Source: own calculation.

\section{DISCUSSION}

As a part of a meticulous and transparent process of guidelines development concerning non-verbal and digital communication in pre-schoolers(age 3-6), we carried out the systematic review of the aforementioned four international articles described in Table 3, to establish whether the elements of both types of communications would have positive effects on pre-schoolers. These studies surveyed the non-verbal and verbal coherence principle and the encoding/decoding process of emotions in pupils age 3-6. Moreover, they surveyed the everyday use of the media to show their revolutionary effects on our lives and the best parenting approach to their children's use of digital tools. As showed by the research taken into consideration, nonverbal communication is a long-debated topic which keeps on changing but has a long history; as a matter of fact, two studies were conducted respectively in 1994 and 2003. On the other hand, digital communication is a more recent, not to say current debate which is evolving before our eyes, day by day. Indeed, the last studies were conducted respectively in 2014 and 2015.

According to Eskritt e Lee (2003), children start to interpret incoherent messages through non-verbal cues earlier than suggested by previous research, which located this ability at age 9-10 (Demorest et al., 1984; DePaulo\& Jordan, 1982; DePaulo et al., 1982; Rotenberg et al., 1989). This finding suggests that preschoolers don't completely rely on the principle "actions speak louder than words". Indeed, as this study shows, preschool children star to distinguish and learn the importance of verbal and non-verbal messages; incoherent conversations don't impede verbal and non-verbal message decoding, but when we encode incoherent messages, children are confused because they can't focus on a channel and a message. Hence, adults must be aware of the stages of development, especially in preschool age, because children don't own certain abilities, such as the verbal and non-verbal coherence principle. As a consequence, certain elements of communication can't be taken for granted. It's fundamental that teachers, in the first place, and whoever helps to raise the child, convey coherent messages and when this is not possible, they must highlight nonverbal stimuli.

Indeed, this study shows that, stimuli for stimuli, pre-schoolers prefer the verbal channel focusing more on words than on gestures; the same channel is chosen with a non-verbal relevance since preschool (Eskritt M. \& Lee K., 2003, p. 38).

According to Boyatzis and Satyaprasad (1994), pre-schoolers don't completely own emotional and gestural competences but also encoding and decoding abilities; they just start to develop them. In preschool, pupils start to develop these abilities until they get a full competence. This research analyses and shows the 
aforementioned aspects; research subjects of 4 and 5 years old were more accustomed to emotions rather than to gestures; to encode rather than to the decode process. For what emotions are concerned, they are part of life since the beginning and both parents and teachers can help children to learn where they come from and how cope with them in the most productive way; in that way, they will finally have the emotional competence. Hence, pupils in preschool can have both encode and, to a lesser extent, decode abilities. The development of the latter, encoding first and decoding later, isn't simultaneous because, as in other process, comprehension comes before production: a child can't express an emotion o gesticulate without learning how to do them first.

Concerning gestures, their use and promotion is pivotal because it enhances the learning process also in preschool. (Boyatzis C. \& Satyaprasad C., 1994, p. 50).

The digital revolution has influenced the individuals' everyday lives. In this regard, Cinque and Brown (2015) have showed how the digital tools fill the lives of Australian university students on different levels, when studying, working, relaxing etc. After quantifying how many hours the subjects spend surfing the Internet, the researchers have dwelt on the Internet overtaking on the TV; more and more people admit preferring the new media over the TV both concerning their free time, for entertainment, and the search for information about education, work, newspaper, politics etc. which is faster. Another aspect concerns the age. The 367 study participants weren't equal in age (peer); on the contrary, the age range was wide, going from 17 to 55 years. This proves that the digital revolution has infected everyone in a short time. As showed by recent research, the media usage data increased exponentially making obvious the effect of the revolution: everyone, from children to older people, from one place to another is affected. (Cinque T. \& Brown A., 2015, p. 15).

Finally, considering Wu et. al. (2014) it is possible to affirm that the digital media are widely available to families and their children in preschool age, as a fully accepted part of everyday life. This requires parents to supervise their children in order to optimize their health and development. The excessive use of media can modify the emotional, psychological and social aspect of a child's everyday life but also their family and school life. Being their children's cognitive and functional abilities at an early stage of development, parents play a pivotal role in promoting an appropriate and safe use of technology; there is evidence that the most functional parenting approach isn't the restrictive one, nor the instructive or the collaborative one, but rather a combination of the three approaches. Nevertheless, imposing restriction on children at this age, can backfire and make them wish for a more independent use, thus, provoking an increase of negative behaviour; redundant and repetitive representation of unwanted behaviours can lead children to develop expectations, perceptions and thoughts of said behaviours. (Wu et al., 2014, p. 7). Instead, when we use an instructive approach, it has been noticed that the following discussion increases the development of the critical thinking skill and leads children to be more judgmental of media contents. The digital natives have the right to grow up using and getting in touch with digital technologies, but being unable to manage time and make the appropriate choice, children must be followed by adults, be they parents, tutors and teachers. As a matter of fact, this study has taken into greater consideration the role of the adult, especially as a guide and support for the discovery of digital media in preschool age. As this research shows, adults, the parents in this case, are fundamental in order for children not to develop from the age of 3 to 5 , problems in the behavioural sphere which originate from the pictures children see or from being in front of the screen for too long. The parents' main function is to follow their children as a guide in the discovery of such instruments, especially in preschool age, making them understand, through short debates, how to behave and what the negative effects would be if they misused technology. This is the reason why the best approach that a parent can adopt isn't at the extremes, either too permissive or too restrictive, but it's in the combination, a mix, a fair amount of the existing approaches; all of that to follow a balanced and effective path. (Wu et al., 2014, p. 8). 


\section{CONCLUSION}

This research has tried to compile the best possible evidence linking aspects of non-verbal and digital communication; the limit to this revision was the weak connection between the four investigations, which focus on different topics and are chronologically apart and not simultaneous; finding commonality between them was hard, but future research will be able to do so and provide an advanced revision.

Nonetheless, an important observation in the present revision was that words are just a minor part of what we can transmit and communicate through gestures, expressions, emotions and new digital tools; preschool children possess (though not fully) these abilities and therefore adults, teachers and parents, are responsible for supporting their development. It's really important that adults learn to be more conscious of what they communicate, paying special attention to non-verbal communication. When teachers interact with their students, they don'tjust convey subject contents, but also their way of being, their idea of education, attention, respect and understanding towards students; by 3 years old, children begin to understand these messages sent by adults and to respond accordingly. Therefore, being aware of what is communicated, not only through words but also through behaviours, body, expressions and personal sensitivity is crucial.

In order to try and fill the generational gap between teachers and students, which was made bigger by the digital, establishing the guidelines to a new type of teacher training is favourable and strategic; teachers should reflect on the potential of the use of computer and new technologies, so that they can offer a "playfulexploratory" approach to education which teaches through media rather than teaching media. Starting from preschool, teachers and parents have to accompany the digital natives towards a critical use of the technological tools: in other words, they can help to focus on learning and growing all the tools available to students.

Italian school has a long way to go before being able to make productive use of digital technologies; we need to set strong foundations for the diffusion, across the country, of an awareness of the potential and limits of a didactic approach which effectively uses the tools provided by the information and communication technologies; all of this, without overestimating them, thinking that they can solve multiple school problems and without rejecting them, as if they were responsible for the students' failures and difficulties. School reflects the complexity of the contemporary society in which we all live and doesn't tolerate shortcuts or simplifications in solving its problems. Finally, this research hasn't investigated nor practically presented non-verbal and digital communication in preschool, describing processing and transmission methods, but it has confined itself to providing a framework, giving a theoretical outline of the situation of today's students, who are digital native, and of teachers and parents, who are digital immigrants.

\section{REFERENCES}

Balbi, G., Magaudda, P. (2014). Storia dei media digitali: rivoluzioni e continuità. Bari, Italia: Laterza. 1 15. https://doi.org/10.1353/tech.2017.0104

Boyatzis, C., Satyaprasad, C. (1994). Children's facial and gestural decoding and encoding: relations between skills and with popularity. Journal of Nonverbal Behavior, March 1994, Volume 18, Issue 1, pp 37-55. https://doi.org/10.1007/bf02169078

Bozzola, E., Spina, G., Ruggiero, M., Memo, L., Agostiniani, R., Bozzola, M., Corsello, G.,Villani, A. (2018). Media devices in pre-school children: therecommendations of the Italian pediatricsociety. Italian Journal of Pediatrics, volume 44, Article number: 69. https://doi.org/10.1186/s13052-018$\underline{0508-7}$ 
Brabazon, T. (2016). Learning to leisure? When social media becomes educational media. http://www.digitalcultureandeducation.com/cms/wpcontent/uploads/2014/07/brabazon.pdf

Cameron, H. \& Xu, X. J Nonverbal Behav (2011) 35: 155. https://doi.org/10.1007/s10919-010-0101-2

Cartmill, E. A., \& Goldin-Meadow, S. (2016). Gesture. In D. Matsumoto, H. C. Hwang, \& M. G. Frank (Eds.), APA handbooks in psychology. APA handbook of nonverbal communication (pp. 307-333). Washington, DC, US: American Psychological Association. http://dx.doi.org/10.1037/14669-012

Cinque, T., Brown, A. (2015). Educating generation next: Screen media use, digital competencies and tertiary education. http://www.digitalcultureandeducation.com/cms/wpcontent/uploads/2015/03/sinque.pdf

D’Angiò, G. (2009). La comunicazione efficace con i bambini. http://www.lascuolapossibile.it/articolo/lacomunicazione-efficace-con-i-bambini/

Del Nista, P. L., Parker, J., Tasselli, A. (2014). Meeting. Firenze, Italia: G. D’Anna.

Eskritt, M. \& Lee, K. Journal of Nonverbal Behavior (2003) 27: 25. https://doi.org/10.1023/A:1023614123081

Faralli, R. (2013). Non rompere le "bolle prossemiche". https://onnoffmagazine.com/2013/07/06/nonrompere-le-bolle-prossemiche/

Ferranti, C. (2014). I sistemi di comunicazione non verbale. http://docenti.unimc.it/clara1.ferranti/teaching/2014/13354/files/comunicazionenon-verbale

https://doi.org/10.1007/978-88-470-0706-2_8

Ferri, P. (2012). Nativi digitali: chi sono? cosa saranno?. https://www.giuntiscuola.it/lavitascolastica/magazine/opinioni/direzionidigitali/page3/

Garassini, S., Romano, G. (2001). Digital Kids. Guida ai migliori siti web, CD-ROM, e videogiochi per ragazzi e bambini. Milano, Italia: Raffaello Cortina

Grushka, K., Donnelly, D., Clement, N. (2014). Digital culture and neuroscience a conversation with learning and curriculum. http://www.digitalcultureandeducation.com/cms/wpcontent/uploads/2014/12/grushka.pdf

Joseph, I. (1994). Display rule behavior and understanding in preschool children. http://eds.a.ebscohost.com/eds/pdfviewer/pdfviewer?vid=15\&sid=599ed6dd7a0c-4791-b1f67e8716ccfe45\%40sessionmgr4009

Manca, M. (2015). Bambini e adolescenti sempre più curvi a causa della postura da smartphone. https://doi.org/10.18356/a03335af-it

Mantovani, S., Ferri, P. (2008). Digital Kids. Milano, Italia: ETAS.

Matsumoto, D., Hwang, H. C. (2016). The cultural bases of nonverbal communication. http://web.a.ebscohost.com/ehost/pdfviewer/pdfviewer?vid=2\&sid=7e14fcd6-5027-4fd1-96112bedc492ecfd\%40sessionmgr4007

Matsumoto, D., Hwang, H. C., Frank, M. (2016). The body: postures, gait, proxemics and haptics. https://doi.org/10.1037/14669-015

McRae, L. (2015). Teaching in an age of ubiquitous computing: A decelerated curriculum. http://www.digitalcultureandeducation.com/cms/wpcontent/uploads/2015/08/mcrae.pdf

Mui, P., Goudbeek, M., Swerts, M., Hovasapian, A. (2016). Children's Nonverbal Displays of Winning and Losing: Effects of Social and Cultural Contexts on Smiles. https://doi.org/10.1007/s10919-016$\underline{0241-0}$

Patterson, M., Quadflieg, S. (2016). The physical environment and nonverbal communication. http://web.a.ebscohost.com/ehost/pdfviewer/pdfviewer?vid=2\&sid=7e14fcd6-5027-4fd1-96112bedc492ecfd\%40sessionmgr4007 
Prensky, M. (2001). Digital Natives, Digital Immigrants. http://www.marcprensky.com/writing/Prensky\%20\%20Digital\%20Natives,\%20Digital\%20Immigrants\%20-\%20Part1.pdf

Radice, G. (2017). Come le nuove tecnologie ci stanno cambiando: la iGeneration. http://www.stateofmind.it/2017/04/igeneration-nuove-tecnologie/

Sanseviero, I., Cassese, F.P., Fonzo, E., Altavilla, G., D'elia, F. (2019) Study on the master's degree in sciences of sports evaluation and sport for disabled at the University of Salerno, Italy, Journal of Human Sport and Exercise, 14 (Proc2), pp. S239-S244. https://doi.org/10.14198/ihse.2019.14.proc2.12

Scialò L. (2016). Rivoluzione digitale: cosa significa e situazione in Italia. https://www.webeconomia.it/rivoluzione-digitale-italia/10266/

Valentini, M., Castriconi, S. (2007). L'altro linguaggio. Perugia, Italia: MargiacchiGaleno.

Vayola, P. (2016). I rischi e le opportunità del digitale a scuola. Spunti di riflessione per progettare la formazione dei docenti. http://www.fupress.net/index.php/formare/article/view/18196/17323

Wu, C., Fowler, C., Lam, W., Wong, H., Wong, C., Loke, A. (2014). Parenting approaches and digital technology use of preschool age children in a chinese community. https://doi.org/10.1186/18247288-40-44

Zimic, S. (2009). Not so 'techno-savvy': Challenging the stereotypical images of the 'Net generation'. http://www.digitalcultureandeducation.com/cms/wpcontent/uploads/2010/01/dce1020_zimic_2009.p $\underline{\mathrm{df}}$ 